\title{
An Overview of Drugs Used in COVID-19: A Pharmacotherapeutic Approach
}

\author{
Architha Aithal ${ }^{1}$ \& Edwin Dias ${ }^{2 \& 3^{*}}$ \\ ${ }^{1}$ Final Year Pharm D., Srinivas College of Pharmacy, Valachil, Mangalore, Karnataka State, India \\ ORCID: 0000-0003-2361-5166; E-mail: aithalarchitha@gmail.com \\ ${ }^{2}$ Professor \& Head, Department of Paediatrics, Srinivas Institute of Medical Sciences and \\ Research Centre, Mangalore, Karnataka State, India \\ ${ }^{3}$ Adjunct Research Professor, College of Allied Health Sciences, Srinivas University, Mangalore, \\ India \\ ORCID: 0000-0001-6266-795X; Email: dredwindias@ gmail.com
}

Area/Section: Health Sciences.

Type of the Paper: Review based Analysis.

Type of Review: Peer Reviewed as per $|\mathrm{C}| \mathrm{O}|\mathrm{P}| \mathrm{E} \mid$ guidance.

Indexed in: OpenAIRE.

DOI: https://doi.org/10.5281/zenodo.4604474

Google Scholar Citation: IJHSP

\section{How to Cite this Paper:}

Aithal, Architha, \& Dias, Edwin, (2021). An Overview of Drugs Used in COVID-19: A Pharmacotherapeutic Approach. International Journal of Health Sciences and Pharmacy (IJHSP), 5(1), 34-54. DOI: https://doi.org/10.5281/zenodo.4604474

International Journal of Health Sciences and Pharmacy (IJHSP)

A Refereed International Journal of Srinivas University, India.

(C) With Author.

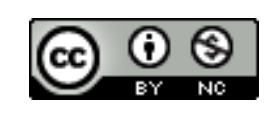

This work is licensed under a Creative Commons Attribution-Non-Commercial 4.0 International License subject to proper citation to the publication source of the work.

Disclaimer: The scholarly papers as reviewed and published by the Srinivas Publications (S.P.), India are the views and opinions of their respective authors and are not the views or opinions of the SP. The SP disclaims of any harm or loss caused due to the published content to any party. 


\title{
An Overview of Drugs Used in COVID-19: A Pharmacotherapeutic Approach
}

\author{
Architha Aithal ${ }^{1}$ \& Edwin Dias ${ }^{2 \& 3 *}$ \\ ${ }^{1}$ Final Year Pharm D., Srinivas College of Pharmacy, Valachil, Mangalore, Karnataka State, India \\ ORCID: 0000-0003-2361-5166; E-mail: aithalarchitha@gmail.com \\ ${ }^{2}$ Professor \& Head, Department of Paediatrics, Srinivas Institute of Medical Sciences and \\ Research Centre, Mangalore, Karnataka State, India \\ ${ }^{3}$ Adjunct Research Professor, College of Allied Health Sciences, Srinivas University, Mangalore, \\ India \\ ORCID: 0000-0001-6266-795X; Email: dredwindias@ gmail.com
}

\begin{abstract}
Coronavirus originated pandemic disease also called Corona Virus Disease 2019 (COVID-19) is spread all over the world causing severe acute respiratory syndrome (SARS) called SARS-CoV-2 poses a difficult challenge to scientists, researchers, and practitioners to discover effective drugs for prevention and treatment. By using a huge amount of clinical data obtained from many SARS-CoV2 infected people, clinicians are trying to gather accurate evidence for effective treatment and also developing a suitable vaccine system for the prevention of spread of infection for many more people. With no proven therapies which can treat and prevent SARS-CoV-2 is developed until now, there is an opportunity for new researchers in virology to make such an attempt at this crucial time. In this regard, currently, two strategies are active. The first kind of strategy is on developing completely new molecules to prevent and treat this disease, or the second strategy is on testing the effectiveness of already available antivirals and antimalarials for possible potential recovery and prevention. This is done by testing several antivirals (Remdesivir, Favipiravir, etc) and antimalarials (Chloroquine, Hydroxychloroquine, etc) for their potential therapies. Studies show that the most promising therapy is the use of antiviral Remdesivir. Remdesivir has shown the potential ability to exhibit vitro activity to control COVID-19. The drug is currently being tested by ongoing randomized trials. Until a widely accepted drug reaches the global market, different antiviral treatment strategies are used under urgent investigation. In this article, we review the latest research developments related to the systematic treatments for COVID-19 reported from various research labs of different countries. The article also provides a summary of various clinical research experience, intermediate results, and treatment guidance to combat the novel coronavirus epidemic based on pharmacotherapeutic analysis, along with insights to the attempts on vaccine development across the world in order to curb the COVID pandemic.
\end{abstract}

Keywords: COVID-19, Coronavirus disease 2019, SARS-CoV-2, Optimum therapy, Treatment \& prevention.

\section{INTRODUCTION :}

The global pandemic of coronavirus disease 2019 (COVID-19) caused by severe acute respiratory syndrome coronavirus 2 (SARS-CoV-2 member of the family Coronaviridae and order Nidovirales) started in a Chinese town called Wuhan in December 2019, and has spread to China initially and then worldwide [1]. Globally, there have been 18,354,342 confirmed cases of COVID-19, including 696,147 deaths, reported to the World Health Organisation (as of 3:00 pm CEST, 5 August 2020) affecting 213 countries and territories around the world [2]. America has reported 9,841,842 confirmed cases to date being the highest affected WHO region, followed by Europe with 3,451,556 confirmed cases. India has reported 1,908,254 COVID-10 positive cases and 39,795 death reports [3]. This pandemic spread the world over caused by the SARS-CoV-2 presented an unexperienced challenge to search effective drugs for cure and prevention. SARS-CoV-2 is found to be transmitted from human-to-human via droplets, contaminated hands or surfaces has been described, with incubation times of 2-14 days [4]. It is also reported that an extended incubation period of as long as 19 days 
in unusual circumstances [5]. As SARS-CoV-2 has been found to persist on surfaces up to $96 \mathrm{~h} \mathrm{[6]} \mathrm{and} \mathrm{other}$ coronaviruses for up to 9 days [7] and hence it is predicted that the fomites may be a large source of transmission. Various modelling studies on basic case reproduction (BCR) rate predicts that the estimated to the range is from 2 to 6.47 [8] and for comparison purposes, the BCR of SARS was 2 and the BCR of pandemic flu H1N1 2009 was 1.3 [3]. It is observed that the clinical symptoms of COVID-19 are different for different patients, ranging from an asymptomatic state to severe respiratory distress syndrome to multiorgan dysfunction. Fever, dry cough, myalgia, and fatigue are found to be common clinical symptoms and features like headache, haemoptysis, sputum production, abdominal pain, and diarrhoea are found to be less common [9]. Bilateral pneumonia is observed in nearly $75 \%$ of patients [10].

Compared to SARS-1 and MERS-CoV infections, COVID-19 patients show different symptoms including prominent upper respiratory tract signs, sneezing, rhinorrhoea, or sore throat, indicating the greater preference of virus action for infecting at the lower respiratory tract [11]. The lethality rate (the ratio of a total number of deaths for a given disease in relation to the total number of patients) of COVID-19 has been significantly lower when compared to SARS-1 and MERS-CoV epidemics, but it is estimated that about one in five individuals who infected worldwide may turn into severe risk [5]. Many times, it is also observed that the characteristic features of COVID-19 are the same in both pregnant and non-pregnant women [14]. In many cases of COVID-19 patients, severe complications like hypoxaemia, acute ARDS, shock, acute cardiac injury, arrythmia, and acute kidney injury have been observed [11], [12]. In a study, using 99 patients, it is observed that $17 \%$ of patients developed acute respiratory disease syndrome (ARDS) and, among them, $11 \%$ died because of multiple organ failure [12]. Approximately 8 days is observed as the median duration from the first symptoms to ARDS status [13]. In the progression stage, an extreme rise in inflammatory cytokines is also observed including IL2, IL7, IL10, GCSF, IP10, MCP1, MIP1A, and TNF $\alpha$ [12]. It is also recorded a high level of IL1 $\beta$, IFN- $\gamma$, IP10, and MCP1 in COVID-19 patients [11] and some ICU-admitted patients had a higher concentration of granulocyte-colony stimulating factor (GCSF), IP10, MCP1A, MIP1A, and TNF- $\alpha$ [11]. Common laboratory abnormalities observed among COVID-19 patients include lymphopenia [12], [4], [13], prolonged prothrombin time, and lifted lactate dehydrogenase [13] and there were more laboratory abnormalities in ICU-admitted patients compared to non-ICU patients [13], [11]. Some symptoms like aspartate aminotransferase, creatine kinase, creatinine, and C-reactive protein were also seen in some patients even most of the patients have shown normal serum procalcitonin levels [4], [13], [11] [15].

The imaging patterns of COVID-19 are found to be similar to SARS-CoV and MERS-CoV infections [16]. Bilateral pulmonary parenchymal ground-glass and consolidative pulmonary opacities were observed in typical CT scanning images and sometimes with a rounded morphology and peripheral lung distribution were also seen [17]. In the 21 initial chest CT scans, ground-glass opacities or consolidation is observed in eightysix percent of patients and more than one lobe affected in $71 \%$ with bilateral involvement observed in $76 \%$ [18]. A chest CT scan study of imaging pattern also revealed that severe lung abnormalities were seen approximately 10 days after the initial onset of symptoms [19] but the consequences of the disease like lung cavitation, discrete pulmonary nodules, pleural effusions, and lymphadenopathy were not seen [18]. In the case of COVID-19 asymptomatic patients, the chest CT imaging abnormalities, have shown rapid evolution from focal unilateral to diffuse bilateral ground-glass opacities that progressed to or co-existed with consolidations within 1-3 weeks. Early diagnosis of COVID-19 pneumonia is possible by combining the assessment of imaging patterns with clinical observations and laboratory findings [20], [21], [22].

While trying to find a solution to COVID-19 pandemic in the form of suitable drug or for the precautionary vaccine, it is known that the most common targets of the virus are the enzymes that virus need to copy their genome, their polymerase and those they need to cut larger proteins into proteases the virus that causes coronavirus is a beta coronavirus SARS CoV -2 make a protease that is required for it to reproduce and is closely resembling to that of the SARS and MERS enzymes. Using this information researchers developed two chemicals named 11a and $11 \mathrm{~b}$ in which $11 \mathrm{a}$ is more potent than $11 \mathrm{~b}$. These drugs were injected into mice and found out it to be non-toxic, and thereafter it becomes a good candidate for the clinical study. If further studies are found to be successful then 11a will begin the phase 1 safety trials in humans.

Clinicians are trying to find the accurate evidence for effective medical treatments for COVID-19 infection through a rapid increase in clinical cases and scientific ongoing researches. The search terms COVID-19 coronavirus or SARS-COV-2 on the search engine ClinicalTrials.gov resulted in 351 active trials, with 291 trials specific to COVID-19 as of June 2020. This paper is an attempt to bring all such efforts of finding a suitable medicine and vaccine for the diagnostics and curing the COVID-19 epidemic through a systematic 
review based on pharmacotherapeutic analysis.

\section{OBJECTIVE :}

This systematic review narrates the summary of the current published scholarly evidence about the major proposed repurposed or experimental treatments for COVID-19 and it also provides a gist of current clinical experience and the treatment guidance for the epidemic coronavirus by analyzing various methods and management of treatments. It is expected that this review will help the new researchers to identify and understand new attempts on the usage of various existing and new molecules for diagnostics and curing the pandemic disease SARS-CoV-2 to provide a reference for future research.

\section{METHODS :}

The systematic review-based analysis is carried out using online databases and relevant scholarly publications related to the drug discovery and treatments for the new COVID-19. Scholarly articles were retrieved using keywords mainly from many research database sites including PubMed, Google Scholar, MEDLINE, and Web of Science. Only scholarly scientific publications from January 2019 to January 2021 are included in the search. The resultant papers including systematic reviews, case studies, and clinical guidelines are used for systematic review and analysis. Data from the chosen articles were summarized and reported as per various treatment methods.

\section{DRUG-BASED TREATMENT / MANAGEMENT ;}

A set of treatments given and recommended by many clinicians for COVID-19 is listed in chronological/systematic order below:

\subsection{Use of Oxygen Therapy}

Even though no specific acceptable treatment is recommended till now for COVID-19 and no vaccine is officially declared or available worldwide, the first step used to treat systematic for addressing respiratory impairment is oxygen therapy. In oxygen therapy, the COVID-19 patient is isolated and supportive care is given including fluid management and antibiotic treatment for any possible secondary bacterial infections [23]. It is found that both non-invasive (NIV) and invasive mechanical ventilation (IMV) to oxygen therapy were necessary depending upon the intensity of respiratory failure refractory to oxygen therapy. Again, intensive care is needed to deal with complicated forms of the disease to offer oxygen therapy [24].

The various reported methods of Oxygen therapy are:

(1) Oxygen Fast Challenge: For patients with respiratory rate greater than 28-30/ min, or with dyspnoea, the oxygen administration by $40 \%$ venturi mask is performed and after few minutes reassessment if situation improves, the treatment should be continued up to six hours and if situation worsens, other noninvasive treatment should be provided.

(2) Intubation and Protective Mechanical Ventilation: Rapid sequence intubation should be used with special precaution where the operator should use protective equipment and preoxygenation for 5 minutes should be also performed via the continuous positive airway pressure (CPAP) method by positioning Heat and moisture exchanger (HME) between the mask and the ventilation balloon [25].

(3) Lung-protective ventilation: Lung protective mechanical ventilation with lower tidal volumes and lower inspiratory pressures with high PEEP should be used to reduce the severity of ARDS patients with a proper strategy of conservative fluid management. The lung protective ventilation should be used more than 12 hours per day [25].

\subsection{Use of Investigational Antivirals}

Since no approved antiviral treatment for coronavirus is available and all COVID-19 treatments are mainly symptomatic, several approaches have been used to fight with viral target and cellular targets. Viral targets include Spike proteins, PLpro Envelope, Nucleaocaspid, etc and cellular targets include Type 2 pneumocytes, Furin, ACE2, transmembrane serine protease 2, Cathepsin L, Two- Pore Channel, etc.

\subsection{Use of Remdesivir}

The broad-spectrum nature of Remdesivir makes it a promising antiviral drug which works against a wide verity of RNA viruses. Remdesivir being a monophosphate prodrug that undergoes metabolism in the body 
to an active C-adenosine nucleoside triphosphate analogue and used for large number of clinical trials by many physicians of several hospitals worldwide. Holshue et al [26], and Xiao et al [27] have published reports on use of Remdesivir to control COVID-19 symptoms even if the efficacy of the drug action is uncertain. But as per some reports [27], Remdesivir, when tested in human cell lines has shown effective inhabitation of coronavirus [28]. Though clarifications are required in this regard, the National Institute of Allergy and Infectious Diseases is presently testing Remdesivir through a double-blind randomised controlled trial with COVID-19 infected patients and the results are yet to be published [29]. Some of the results on such experiment of use of Remdesivir are found effective to shorten recovery time and hence hospital stay but fails to reduce mortality [27]. Remdesivir helps in reducing the recovery time from 15 days to 11 days in carefully chosen hypoxic patients but does not reduce their chances of dying.

\subsection{Use of Chloroquine}

An antimalarial drug Chloroquine shows immunomodulatory effect and capable to actively inhibit SARSCoV-2 in vitro. This is proved by many Clinical controlled trials in the treatment of patients with COVID-19 [30]. It is found that Chloroquine and Hydroxychloroquine have the potential ability to stop viral entry into cells by inhibiting following five effects :

(1) Glycosylation of host receptors,

(2) Proteolytic processing,

(3) By endosomal acidification.

(4) Exhibiting immunomodulatory effects by attenuation of cytokine production, and

(5) By the inhibition of autophagy along with the lysosomal activity in host cells.

The optimum oral dosage of Chloroquine is of $500 \mathrm{mg}$ and for Hydroxychloroquine is $400 \mathrm{mg}$ once or twice a day for satisfactory treatment for COVID-19 [31]. Clinical studies are still going on various prophylaxis benefits of Chloroquine and Hydroxychloroquine and are yet to be disclosed.

\subsection{Use of Arbidol}

Another drug molecule named Arbidol derived from indole is found to be effective to block fusion of Influenza A, Influenza B, and Hepatitis C viruses [32]. It also has shown antiviral effect on against SARSCoV-2 in many cell experiments [33]; and expected to be effective for the treatment of COVID-19 patients. While comparing another antiviral counterpart, Kaletra, Arbidol has shown better therapeutic effect and could be used for reducing the severe sufferings due to COVID-19.

\subsection{Use of Lopinavir/Ritonavir}

Lopinavir/Ritonavir nucleoside molecules analogues to Remdesivir have potential to be used for COVID-19 treatment [34]. In some of the previous study reports, Lopinavir- Ritonavir combined with another antiviral drug called Ribavirin has shown better result while treating the patents of SARS and MERS compared to patients treated with ribavirin alone [13].

Though some of the preclinical studies on use of Ribavirin have reported in vitro activity against coronavirus [30], some systematic studies based on two randomized trails and 21 observations on clinical use of Lopinavir/Ritonavir have shown no considerable benefit and hence inconclusive on its use to improve the clinical outcomes of severe symptomatic COVID-19 disease [35].

\subsection{Use of Favipiravir}

Favipiravir ribofuranosyl-5'-triphosphate shortly called Favipiravir is a prodrug of a urine nucleotide capable to inhibit RNA polymerase by stopping replication of coronavirus and hence approved in India for supportive treatment of emergency patients suffering from COVID-19 by Drug Controller General of India got authorization for emergency usage for infections which are mild and moderate. This approval is based on the clinical trial of 150 mild and moderate patients conducted by a company called Glenmark shown reduction in fever using early data [37]. In another clinical trial based on the data of 80 patients in China showed a decrease in viral load [36]. But the drug also shown severe renal complications, and hepatic impairments in pregnant women.

\subsection{Use of Azithromycin}

Azithromycin, being an antibiotic is widely prescribed by many doctors and pharmacists for COVID-19 
patients even if it failed to give any relief for viral infections. Antibiotics like Azithromycin have only warranted in patients to avoid secondary bacterial infection for some COVID-19 patients in the later stage of their disease. In such cases, Azithromycin has exhibited anti-inflammation activity to fight with chronic inflammation [38-39]. But it is argued that instead of curing SARS-CoV-2 infection, Azithromycin worsens antibiotic resistance of the patients [40].

\subsection{Use of Ivermectin}

Ivermectin is basically an anti-parasitic drug used to treat infections from worms historically in South America and India. Ivermectin has used to treat COVID-19 patents and showed in vitro reduction of viral RNA in Vero-hSLAM cells 2 hours post infection. But this study is still in early stage and no effective dose is established. Ivermectin has shown promise in animals for treatment of respiratory viruses at substantially higher dosage level than commonly used at normal human dose [41]. Further intensive research is required to conclude the effectiveness of the drug in human coronavirus treatment [42].

\subsection{Use of Nitazoxanide}

As per the reports [43], Nitazoxanide is expected to decrease the replication of respiratory viruses in cell culture including SARS-CoV-2 virus. The data on research of using Nitazoxanide suggest that it has in vitro inhibitory effect against SARS-CoV-2 and other coronaviruses at attainable drug concentration level and inhibits pro-inflammatory cytokines of virus growth as well as shown satisfactory safety level for human clinical use [44]. For prevention of COVID-19, this drug is tested in high risk population and two phase 3 trails have been conducted and the third trial is planned for early treatment of COVID-19 is planned [44].

However, four treatment arms (Remdesivir, Chloroquine or Hydroxychloroquine, Lopinavir/Ritonavir, or Lopinavir/Ritonavir plus interferon beta-1a) out of ten discussed above, are suggested by WHO in its ambitious experiment called SOLIDARITY - a global megatrial for treating COVID-19 patients, which is randomized with standard care and as of July $04^{\text {th }} 2020$, observed that these drugs are showing little or no reduction in death of patients compared with standard care.

\section{INVESTIGATION BASED IMMUNOMODULATORY AGENTS :}

Many immune modulators are used for boost immunity of living body for diseases and also monitors immune systems function in the body by bringing the ratio of different immune cells back into balance. There are two types of immune modulators which include specific immune modulators and non-specific immune modulators. Specific immune modulators are used for curing specific infections and non-specific immune modulators are general type used for any type of infection [45]. Some of specific immune modulators include:

(i) Anti-cytokines such as interleukin (IL)-1 and IL-6 receptor antagonists like anakinra, tocilizumab, sarilumab, siltuximab, etc

(ii) Janus kinase (JAK) inhibitors like baricitinib, ruxolitinib, etc

(iii) Anti-tumor necrosis factor- $\alpha$ like adalimumab, infliximab, etc

(iv) Granulocyte-macrophage colony-stimulating factors like gimsilumab, lenzilumab, namilumab, etc and

(v) Convalescent plasma, specific immune modulators include with promising to negative trials and other data.

Some of non-specific immune modulators include:

(i) Human immunoglobulin,

(ii) Corticosteroids such as Dexamethasone, Interferons, Statins, Angiotensin pathway modulators, macrolides like Azithromycin, Clarithromycin, etc,

(iii) Hydroxychloroquine and Chloroquine,

(iv) Colchicine, and

(v) Prostaglandin D2 modulators such as Ramatroban.

\subsection{Use of Janus Kinase Inhibitors}

Janus kinase (JAK) inhibitors are expected to play an important role in managing the symptoms of COVID19 patients by inhibiting essential cytokine signalling involved in immune-mediated inflammatory response to reduce viral infection [46]. JAK has ability to interrupt intracellular entry of any virous [47]. But one of the demerits observed is severe reaction after initiation of Ruxolitinib were reported in two COVID-19 
patients, and hence ended with discontinuation of drug [48]. Further in both patients, a progressive decrease in hematocrit values observed and in one patient deep-tissue infection is observed. Thus, the possibility of recommendation of JAK inhibitor for inflammatory cytokine storm for COVID-19 is doubtful. Baricitinib, another member of JAK inhibitors is also studied its effectiveness as virus inhibitor individually and along with Remdesivir and found its adverse effect profile [37]. Recently, National Institutes of Health (NIH) in its COVID-19 Treatment guidelines recommended not to use JAK inhibitors due to its broad immunosuppressive effect which outweighs the possible benefits [52].

\subsection{Use of Anti-tumor Necrosis Factor-a}

Anti-tumor Necrosis Factor- $\alpha(\mathrm{TNF} \alpha)$ plays an important role in controlling acute inflammatory reactions and produces IL-1 and IL-2 [53]. Use of TNF $\alpha$ in SARS-CoV-2 patients resulted in enzyme reaction in such a way that it supported virus entry and tissue damage [56]. An excess amount of TNF $\alpha$ is found in the plasma and tissues of patients with COVID-19 [54], which are reported to be produced by the high numbers of monocytes expressing TNF $\alpha$ [55]. In other report, it is proposed that injection of anti-TNF $\alpha$ antibody can decrease TNF amount in blood [58] so that it can be used as anti-inflammatory against COVID-19 virus [57, 58]. According to one opinion, anti-TNF $\alpha$ therapy is effective and should initiated to fight against coronavirus as potential therapy.

\subsection{Use of Glucocorticoids}

Glucocorticoids (GCS) shows immune response and exert inhibitory effects on broad spectral virus infections. Glucocorticoids are already used for many acute diseases of inflammatory and autoimmune disorders [58]. Three mechanisms are proposed to explain anti-inflammatory and immunosuppressive effects of GCS that include [59]:

(i) Direct effects on gene expression by the binding of glucocorticoid receptors to glucocorticoid-responsive elements,

(ii) Indirect effects on gene expression through the interactions of glucocorticoid receptors with other transcription factors i.e., $\mathrm{NF}-\mathrm{k} \beta$ and activator protein 1 ,

(iii) Glucocorticoid receptor-mediated effects on second-messenger cascades [59].

Glucocorticoids have been used for curing acute distress respiratory syndrome (ADRS) [[60], [61], [62]] and attempted to use to the treatment of severe COVID -19 patients by many hospitals in different countries based on local therapeutic guidelines [63]. However, existing evidence is inconclusive or does not support for GCS treatment of COVID-19 patients to date [64]. Prudent use with low-to-moderate doses and short courses of treatment could be advised in selected cases [69] for patient stabilization, but with utmost care to the patient who are critically ill with SARS-CoV-2 pneumonia [65-68]. Based on above, Wang et al. have suggested that the inappropriate use of broad-spectrum antibiotics should be avoided unless there is evidence of secondary bacterial infection [70].

Dexamethasone cuts the mortality in hypoxic patients and those on mechanical ventilators but not in mildly sick patients. In fact, steroids up the death rates in such patients

\subsection{Use of Statins}

Statins is a class of lipid-lowering drug molecule that reduce illness and mortality in patients of cardiovascular disease and used as cholesterol-lowering drugs. Satin inhibits pro-inflammatory cytokine production in mononuclear, synovial and endothelial cells. Statins exhibits immunomodulatory effects through T-cell activation [71,72] and hence was suggested to use in treatment of patients who were suffering from Ebola virus disease [73]. Clinical trials have shown that statin improves acute lung injury [74, 75]. No data is available on use of statins on SARS-2-CoV-19 patients till date. New clinical studies are required to the possibility of use of statins for treating the severe COVID-19 patients [76].

\subsection{Use of Anticoagulants: Heparin and Fondaparinux}

Anticoagulants like heparin and fondaparinux is used for inhibiting coagulation of the blood. It is known that severe SARS2-CoV-2 viral infection is associated with pro-inflammatory clot pathway hyperactivity. Many severe COVID-19 patients are found to be suffering from venous or pulmonary thromboembolism due to high level of D-dimer which is an indicative of the activation of the intravascular coagulation [[77], [78], [79]]. Although D-dimer levels are elevated in most patients with blood clots, D-dimer levels also are elevated 
in many other disorders including infection [80], [81]. Such hyper-inflammatory or intra-pulmonary inflammation might influence a lung centric pulmonary intravascular coagulopathy [82]. In such cases Anticoagulation therapy using heparin or fondaparinux is recommended for treating COVID-19 patients when high D-Dimer levels are detected [71].

\subsection{Use of Renin-Angiotensin-Aldosterone System Inhibitors}

The renin-angiotensin-aldosterone system (RAAS) inhibitors, like ACEi and ARB, not only supports the cardiovascular protective therapies but also as anti-inflammatory and immunomodulatory agents [84]. These inhibitors convert angiotensin (Ang) I to Ang II, in human lungs [85]. It is argued that angiotensinaldosterone receptors are the human cell entry points for SARS-CoV-2 [85]. Theoretically, ACEIs and ARBs can increase SARS-CoV-2 attachment by upregulating action [86], although this was not supported by any clinical trial data and is an urgent research priority. Opposing to this evidence, renin-angiotensin-aldosterone system (RAAS) inhibitors may reduce the pain of lung injury in some viral pneumonias [87]. It is also known that Ang II fosters inflammation, oxidation, vasoconstriction, and fibrosis [88]. Hence it is argued that a pharmacological agent that inhibits the production of Ang II may be useful for preventing lung injury and improving systemic health. In a study of 6272 patients in Italy with confirmed SAR-CoV-2 infection revealed that there is no evidence that the use an ACEi or ARB affected the risk of COVID-19, severity of the clinical manifestations, or the course of infection [90]. While the use of an ACEi or ARB was more commonly used in patients with COVID-19 than in controls, this was due to the higher prevalence of cardiovascular disease in these patients.

Hence it is demonstrated that use of an ACEi and ARB is not associated with an increased risk of infection with SARS-CoV-2. Thus, these agents should not be discontinued, unless the drugs cannot be tolerated due to hemodynamic instability [91]. If a COVID-19 patient has an indication for these agents, therapy should be started or continued.

\section{CONVALESCENT PLASMA THERAPY :}

Plasma therapy is a clinical solution to treat viral diseases by infusion of convalescent plasma (CP) to patient body. The injected convalescent plasma is able to induce an immune response with the production of neutralizing antibodies in patient body. Usually, convalescent plasma can be manufactured by collecting blood or apheresis plasma from a convalescent donor. The mechanism of function of CP therapy is clearance of viremia, which typically happens 10 to 14 days after infection. Based on evidence, it is effective if CP transfusion from COVID-19 patients who have recovered and having a high neutralizing antibody titre (NAT) can provide short-term passive immunity that can be used in the prevention of infection for the patients with COVID-19 [92, 93, 94, 95, 96, 97].

Based on historical evidence, Convalescent plasma has shown improved survival rate of patients suffering from Ebola, SARS, flaviviruses, H1N1, and MERS, [95, 97, 98]. These results show that the patients who obtained CP treatment within 14 days after initial symptoms, could recover in a better way compared to the patients who received CP treatment later in the disease course [92, 93, 97, 99]. No report on serious complications or adverse effect on patient on use of $\mathrm{CP}$ is available but many studies and results of $\mathrm{CP}$ usage are of low quality and mainly uncontrolled [100-101]. As per the report published in 2020 by Shen et al. [102], on five critically ill COVID-19 patients with ARDS requiring mechanical ventilation who received two consecutive convalescent plasma transfusions containing high-titer neutralizing antibodies (NAT of 80480) in conjunction with continued methylprednisolone and antiviral treatment [102]. Plasma transfusion was administered to COVID-19 patients 10-22 days after symptoms found. All five patients slowly recovered clinically. In four patients, ARDS resolved 12 days after plasma transfusion, three patients were recovered from ventilation requirement within 2 weeks, the body temperature of four patients reached to normal level within 3 days. In all these patients, Sequential Organ Failure Assessment (SOFA) score level is decreased, Coronaviral loads decreased and recorded negative within 12 days after transfusion.

In another pilot study [100], after treating with a single CP transfusion to 10 adults with severe COVID-19, the symptoms such as fever, cough, shortness of breath, and chest pain were improved in all patients within 1-3 days. Compared to the conditions 14 days before, the patients showed variable degrees of improvement on chest CT, and neutralizing antibodies were increased. Less than $1 \%$ of patients had major adverse effect like circulatory overload, transfusion-related acute lung injury, and severe allergic transfusion reaction, and only two of these events were clinically judged as certainly associated with the transfusion [100]. Contrary 
to this, a Chinese clinical report highlighted the results of convalescent plasma therapy on 103 COVID-19 patients with severe or life-threatening disease found no significant improvement clinically within 28 days, including mortality, or time to hospital discharge [102].

\section{USE OF NITRIC OXIDE :}

The inhaled nitric oxide (iNO) has shown potential advantage on controlling viral infection like SARS-CoV and is studied since 2004. Nitric Oxide inhalation effect is also studied in virus infected patients with pulmonary complications and it is observed that the pulmonary hypertension has been reversed in many cases. The published results show that iNO also improved decreased the length of ventilatory support by improving severe hypoxia [94]. The cause of inhaled nitric oxide while treating severe COVID-19 patients is under study with an objective of curing and preventing progress of disease in patients who have severe ARDS [95]. The clinical researchers are currently using iNO for checking efficacy and safety prior to supporting ventilation [96]. Due to the high cost of iNO that is more than $\$ 100$ per hour, the routine use of iNO for severe COVID19 pneumonia patients is not recommended by the Society of Critical Care Medicine and instead of it, other rescue strategies including one time trail only to ventilated patients who have severe ARDS and hypoxemia symptoms is suggested [74].

Drug based treatment and immunomodulatory agents-based treatments are discussed and analysed in above section. The summary of the analysis in depicted in table 1 with various drugs used in treatments along with their advantages and limitations.

Table 1: Summery of various drugs/treatments along with their advantages and limitations

\begin{tabular}{|c|c|c|c|c|}
\hline $\begin{array}{l}\text { S. } \\
\text { No. }\end{array}$ & $\begin{array}{l}\text { Drug/ } \\
\text { Treatment }\end{array}$ & Advantage & Limitation & Reference \\
\hline 1 & Oxygen Therapy & $\begin{array}{ll}\text { Addresses } & \text { respiratory } \\
\text { impairment } & \end{array}$ & $\begin{array}{l}\text { Hospitalization and } \\
\text { Intensive care is required }\end{array}$ & [23-25] \\
\hline 2 & $\begin{array}{l}\text { Investigational } \\
\text { Antivirals }\end{array}$ & $\begin{array}{l}\text { to fight with viral target and } \\
\text { cellular targets }\end{array}$ & $\begin{array}{l}\text { Treatments are pure on } \\
\text { symptotic }\end{array}$ & - \\
\hline 3 & Remdesivir & $\begin{array}{l}\text { Effective to shorten recovery } \\
\text { time and hence hospital stay }\end{array}$ & $\begin{array}{l}\text { It fails to reduce } \\
\text { mortality }\end{array}$ & [26-29] \\
\hline 4 & Chloroquine & $\begin{array}{l}\text { Exhibiting immunomodulatory } \\
\text { effects by stopping viral entry } \\
\text { into cells }\end{array}$ & $\begin{array}{l}\text { Prophylaxis benefits are } \\
\text { yet to be disclosed }\end{array}$ & [30-31] \\
\hline 5 & Arbidol & $\begin{array}{l}\text { Better therapeutic effect and } \\
\text { could be used for reducing the } \\
\text { severe sufferings }\end{array}$ & $\begin{array}{l}\text { Exact therapeutic actions } \\
\text { are not known }\end{array}$ & [32-33] \\
\hline 6 & $\begin{array}{l}\text { Lopinavir/Riton } \\
\text { avir }\end{array}$ & $\begin{array}{l}\text { Being nucleoside molecules, } \\
\text { they are expected to decrease } \\
\text { severe symptoms of COVID- } \\
19\end{array}$ & $\begin{array}{l}\text { Clinical results shown no } \\
\text { considerable benefit and } \\
\text { hence inconclusive on its } \\
\text { use }\end{array}$ & [30-35] \\
\hline 7 & Favipiravir & $\begin{array}{l}\text { Shown reduction in fever using } \\
\text { early data }\end{array}$ & $\begin{array}{l}\text { Shown severe renal } \\
\text { complications, and } \\
\text { hepatic impairments in } \\
\text { pregnant women }\end{array}$ & [36-37] \\
\hline 8 & Azithromycin & $\begin{array}{l}\text { Avoid secondary bacterial } \\
\text { infection for some COVID-19 } \\
\text { patients in the later stage of } \\
\text { their disease }\end{array}$ & $\begin{array}{l}\text { Also argued that it } \\
\text { worsens antibiotic } \\
\text { resistance of the patients }\end{array}$ & [38-40] \\
\hline 9 & Ivermectin & $\begin{array}{l}\text { Shown promise in animals for } \\
\text { treatment of respiratory viruses } \\
\text { at substantially higher dosage }\end{array}$ & $\begin{array}{l}\text { High dose level may be } \\
\text { required } \quad \text { compared }\end{array}$ & [41-42] \\
\hline
\end{tabular}


International Journal of Health Sciences and Pharmacy

\begin{tabular}{|c|c|c|c|c|}
\hline & & level & normal human dose & \\
\hline 10 & Nitazoxanide & $\begin{array}{l}\text { Argued that it has in vitro } \\
\text { inhibitory effect against SARS- } \\
\text { CoV-2 }\end{array}$ & $\begin{array}{l}\text { Showing little or no } \\
\text { reduction in death of } \\
\text { patients compared with } \\
\text { standard care }\end{array}$ & [43-44] \\
\hline 11 & $\begin{array}{l}\text { Janus Kinase } \\
\text { Inhibitors }\end{array}$ & $\begin{array}{l}\text { It has ability to interrupt } \\
\text { intracellular entry of any virous }\end{array}$ & $\begin{array}{l}\text { Severe reaction after } \\
\text { initiation of ruxolitinib } \\
\text { were reported }\end{array}$ & [46-48] \\
\hline 12 & $\begin{array}{l}\text { Anti-tumor } \\
\text { Necrosis Factor- } \\
\alpha(\mathrm{TNF} \alpha)\end{array}$ & $\begin{array}{l}\text { Controls acute inflammatory } \\
\text { reactions and virus entry and } \\
\text { tissue damage }\end{array}$ & $\begin{array}{l}\text { More research is } \\
\text { required to prove the } \\
\text { ability to fight against } \\
\text { coronavirus as potential } \\
\text { therapy }\end{array}$ & [53-58] \\
\hline 13 & Glucocorticoids & $\begin{array}{l}\text { Shows immune response and } \\
\text { exert inhibitory effects }\end{array}$ & $\begin{array}{l}\text { Inappropriate use of } \\
\text { broad-spectrum } \\
\text { antibiotics may be } \\
\text { dangerous }\end{array}$ & [65-68] \\
\hline 14 & Statins & Improves acute lung injury & $\begin{array}{l}\text { More clinical studies are } \\
\text { required to test the } \\
\text { possibility of usage }\end{array}$ & [71-75] \\
\hline 15 & $\begin{array}{l}\text { Anticoagulants: } \\
\text { Heparin and } \\
\text { Fondaparinux }\end{array}$ & $\begin{array}{l}\text { Anticoagulation therapy for } \\
\text { treating COVID-19 patients } \\
\text { when high D-Dimer levels are } \\
\text { detected }\end{array}$ & $\begin{array}{l}\text { May influence a lung } \\
\text { centric pulmonary } \\
\text { intravascular } \\
\text { coagulopathy }\end{array}$ & [77-82] \\
\hline 16 & $\begin{array}{l}\text { Renin-- } \\
\text { angiotensin-- } \\
\text { aldosterone } \\
\text { system (RAAS) }\end{array}$ & $\begin{array}{l}\text { Reduce the pain of lung injury } \\
\text { in some viral pneumonias }\end{array}$ & $\begin{array}{l}\text { Sometimes drugs cannot } \\
\text { be tolerated due to } \\
\text { hemodynamic instability }\end{array}$ & [85-90] \\
\hline 17 & Plasma therapy & $\begin{array}{l}\text { Produces neutralizing } \\
\text { antibodies in patient body }\end{array}$ & $\begin{array}{l}\text { Rare problems like } \\
\text { circulatory overload, } \\
\text { transfusion-related acute } \\
\text { lung injury, and severe } \\
\text { allergic reactions } \\
\text { observed }\end{array}$ & {$[100-102]$} \\
\hline 18 & $\begin{array}{ll}\text { Nitric } & \text { oxide } \\
\text { (iNO) } & \end{array}$ & $\begin{array}{l}\text { Controlling viral infection \& } \\
\text { Reversing } \\
\text { hypertension }\end{array}$ & $\begin{array}{l}\text { High cost of more than } \$ \\
100 \text { per hours }\end{array}$ & {$[94-96]$} \\
\hline
\end{tabular}

\section{VACCINE DEVELOPMENT STATUS :}

On other hand, in addition to the continued efforts of curing COVID-19 patients, scientific research is growing to prevent the COVID-19 disease by developing a Sars-CoV-2 vaccine. Many universities and pharmaceutical companies worldwide struggling to develop effective vaccine and currently there are more than 100 vaccines are under development stage, out of them, 8-10 are under clinical trial. In this game of vaccine development, China, Russia, UK, USA, Australia, even India are claiming to be ahead and two countries (China and Russia) have released the first vaccines recently [55]. Some of the clinical studies are elaborated below:

(1) Inactivated vaccine is currently in trail 3 phase at Wuhan Institute of Biological Products, National Pharmaceutical Group, China. The phase I clinical trial is designed to evaluate the safety, reactogenicity and immunogenicity of a recombinant adenovirus type-5 (Ad5) vectored COVID-19 vaccine expressing the spike 
glycoprotein have been studied. The primary outcome of vaccine administered 108 healthy adults between age group 18 to 60 years, with 36 received a low dose, 36 a medium dose, and 36 a high dose of vaccine and results were evaluated for adverse events after 7 days following vaccination. After 28 days of vaccination, safety was assessed. The grown specific antibodies were measured with the enzyme-linked immunosorbent assay (ELISA) method. In this study, 81\% (87 participants) reported at least one adverse reaction within 7 days of vaccination. Apart from pain in injection site as common, other include fever, headache, and muscle pain. No other serious adverse reactions reported during 28 days of study. The specific antibody responses against SARS-CoV-2 peaked 28 days after the administration of the vaccine dose and the specific immune response of T lymphocytes was evident from the 14th day [55]. In the II phase, which was a double-blinded, randomized clinical trial, designed to evaluate the immunogenicity and safety of Ad5-CoV which encodes for a full-length spike protein of SARS-CoV-2. The reports of the phase II trial are yet to be published and will provide additional information on the safety and immunogenicity of this vaccine [55].

(2) A company in the United States aimed to study and evaluating the safety, tolerability, immunogenicity, and potential efficacy of up to 4 different SARS-CoV-2 RNA vaccine candidates against COVID-19. The spike sequence is included in two of the candidate vaccines, while the other two include the RBD. The Phase $1 / 2$, which is randomized, observer-blind, placebo-controlled, dose-finding, study is carried out and the results are yet to publish to give additional information.

(3) Another Phase I study in United States was designed to assess the safety, tolerability, and immunological profile of a vaccine administered by intradermal injection followed by electroporation which is a technique used to facilitate the passage of drugs into the cell membrane, through the use of a specific device. A study promoted by the National Institute of Allergy and Infectious Diseases (NIAID) divides the participants into three parallel arms based on the dose of a lipid nanoparticle (LNP)-encapsulated mRNA-based vaccine that encodes for the spike protein of SARS-CoV-2 (mRNA-1273). It is administered through an intramuscular injection on day 1 and day 29 and the subjects will be followed in follow-up for a period of 12 months after the second administration. The results are yet to be published [55].

(4) Though Russia released the first vaccine candidate for COVID-19, it is based on the result of clinical trial tested with just 76 patients and as per Gamaleya Research Institute of Epidemiology and Microbiology in Moscow, the developer of the vaccine, only a small number of citizens from vulnerable groups including medical staff and the elderly can be tested with this vaccine and Russian government issued a certificate stipulates that the vaccine cannot be used widely until 1 January 2021, presumably after larger clinical trials have been completed [103]. This vaccine called Sputnik V - formerly known as Gam-COVID-Vac was approved by the Ministry of Health of the Russian Federation on 11 August 2020. The question is raised worldwide on its safety and efficacy due to the fact that it has not entered phase three clinical trials [103].

(5) The US government has chosen three vaccine candidates to fund for Phase 3 trials under Operation Warp Speed: Moderna's mRNA-1273, The University of Oxford and AstraZeneca's AZD1222, and Pfizer and BioNTech's BNT162. Members of ACTIV have suggested developing safe controlled human infection models (CHIMs) for human trials could take 1-2 years. A sponsor would need to provide data from placebocontrolled trials indicating their vaccine is at least 50\% effective against COVID-19 in order to be authorized for use, according to FDA guidance issued and effective 30 June [104].

(6) Bharath Biotech, in collaboration with the Indian council of medical research (MCRI), and the National institute of virology, designed an inactivated vaccine - Covaxin, is currently conducting phase 3 trials in 25 centers across India. In the view of positive phase 1 and phase 2 results, it is now seeking emergency authorisation.

(7) Covishield, a recombinant, adenovirus vector encoding SARS-CoV-2 Spike (S) glycoprotien, manufactured by Serum Institute of India Private Limited (Vaccine developed in the UK, by OxfordAstraZeneca), and secondary sponsor being Indian Council of Medical Research ICMR, is currently in Phase $2 / 3$, Observer-Blind, Randomized, Controlled Study to Determine the Safety and Immunogenicity of Covishield, with 14 study sites across India. Though International clinical trials of the Oxford-AstraZeneca vaccine revealed that when people were given a half dose followed by a full dose, effectiveness hit $90 \%$, there was insufficient evidence to approve the half-dose, full-dose idea. However, unpublished data suggests that leaving a longer gap between the first and second doses increases the overall effectiveness of the jab - in a sub-group given the vaccine this way it was found to be $70 \%$ effective after the first dose. Backed by phase III trial data from Brazil and United Kingdom, the Serum Institute of India advocates that the Covishield is highly effective. 
Table 2: List of some of the vaccines under phase 2/3 development stages [104]

\begin{tabular}{|c|c|c|c|c|}
\hline $\begin{array}{l}\text { S. } \\
\text { No. }\end{array}$ & $\begin{array}{l}\text { Vaccine } \\
\text { Candidate }\end{array}$ & $\begin{array}{l}\text { Trial } \\
\text { Phase }\end{array}$ & Sponsor & Institution / Lab \\
\hline 1 & $\begin{array}{l}\text { Inactivated } \\
\text { vaccine }\end{array}$ & Phase 3 & $\begin{array}{ll}\text { Wuhan } & \text { Institute of } \\
\text { Biological } & \text { Products; China } \\
\text { National } & \text { Pharmaceutical } \\
\text { Group } & \\
\end{array}$ & $\begin{array}{l}\text { Henan Provincial Center for } \\
\text { Disease Control and Prevention, } \\
\text { China }\end{array}$ \\
\hline 2 & $\begin{array}{l}\text { CoronaVac- } \\
\text { Inactivated } \\
\text { vaccine }\end{array}$ & Phase 3 & Sinovac & $\begin{array}{l}\text { Sinovac Research } \quad \text { and } \\
\text { Development Co., Ltd. }\end{array}$ \\
\hline 3 & mRNA-1273 & Phase 3 & Moderna, NIAID, BARDA & $\begin{array}{l}\text { Kaiser Permanente Washington } \\
\text { Health Research Institute }\end{array}$ \\
\hline 4 & $\begin{array}{l}\text { Bacillus } \\
\text { Calmette- } \\
\text { Guerin } \\
\text { (BCG) live- } \\
\text { attenuated } \\
\text { vaccine }\end{array}$ & Phase $2 / 3$ & \begin{tabular}{|lr} 
University of & Melbourne \\
and Murdoch & Children's \\
Research Institute, Radboud & Redical \\
University & Mediter \\
Center, Faustman & Lab at \\
Massachusetts & General \\
Hospital & \\
\end{tabular} & $\begin{array}{l}\text { University of Melbourne and } \\
\text { Murdoch Children's Research } \\
\text { Institute, Radboud University } \\
\text { Medical Center, Faustman Lab at } \\
\text { Massachusetts General Hospital }\end{array}$ \\
\hline 5 & AZD1222 & Phase $2 / 3$ & $\begin{array}{l}\text { The University of } \\
\text { Oxford, AstraZeneca, IQVI } \\
\text { A }\end{array}$ & $\begin{array}{l}\text { The University of Oxford, \& } \\
\text { Jenner Institute }\end{array}$ \\
\hline 6 & $\begin{array}{l}\text { BNT162 } \\
\text { (Comirnaty) }\end{array}$ & Phase $2 / 3$ & $\begin{array}{l}\text { Pfizer, BioNTech, Fosun } \\
\text { Pharma }\end{array}$ & $\begin{array}{l}\text { Multiple study sites in Europe and } \\
\text { North America }\end{array}$ \\
\hline 7 & Ad5-nCoV & Phase 3 & CanSino Biologics & Tongji Hospital; Wuhan, China \\
\hline 8 & $\begin{array}{l}\text { Adjuvant } \\
\text { recombinant } \\
\text { vaccine } \\
\text { candidate }\end{array}$ & Phase 2 & $\begin{array}{l}\text { Anhui Zhifei Longcom } \\
\text { Biopharmaceutical, } \\
\text { Institute of Microbiology of } \\
\text { the Chinese Academy of } \\
\text { Sciences }\end{array}$ & $\begin{array}{l}\text { Institute of Microbiology of the } \\
\text { Chinese Academy of Sciences }\end{array}$ \\
\hline 9 & ZyCoV-D & Phase 2 & Zydus Cadila & Zydus Cadila \\
\hline 10 & $\begin{array}{l}\text { Covaxin } \\
\text { Inactivated } \\
\text { vaccine }\end{array}$ & Phase 3 & $\begin{array}{l}\text { Bharat Biotech; National } \\
\text { Institute of Virology, India }\end{array}$ & $\begin{array}{l}\text { Bharat Biotech, National Institute } \\
\text { of Virology, India }\end{array}$ \\
\hline 11 & BBIBP-CorV & Phase $1 / 2$ & \begin{tabular}{|lr} 
Beijing & Institute of \\
Biological & Products, \\
National & Pharmaceutical \\
Group, China & \\
\end{tabular} & $\begin{array}{l}\text { Henan Provincial Center for } \\
\text { Disease Control and Prevention }\end{array}$ \\
\hline 12 & GX-19 & Phase $1 / 2$ & Genexine & Genexine \\
\hline 13 & $\begin{array}{l}\text { Sputnik } \quad \text { V } \\
\text { (Viral } \\
\text { Vector) }\end{array}$ & Phase $1 / 2$ & $\begin{array}{l}\text { Gamaleya Research } \\
\text { Institute, Acellena Contract } \\
\text { Drug Research and } \\
\text { Development, Russia } \\
\end{array}$ & $\begin{array}{l}\text { Gamaleya Research Institute of } \\
\text { Epidemiology and Microbiology, }\end{array}$ \\
\hline 14 & $\begin{array}{l}\text { Self- } \\
\text { amplifying } \\
\text { RNA vaccine }\end{array}$ & Phase $1 / 2$ & Imperial College London & Imperial College London \\
\hline 15 & $\begin{array}{l}\text { LUNAR- } \\
\text { COV19 }\end{array}$ & Phase $1 / 2$ & \begin{tabular}{|l|} 
Arcturus \\
Therapeutics and Duke- \\
NUS Medical School \\
\end{tabular} & $\begin{array}{lll}\text { Duke-NUS } & \text { Medical School, } \\
\text { Singapore } & & \end{array}$ \\
\hline 16 & $\begin{array}{l}\text { INO-4800 } \\
\text { DNA vaccine }\end{array}$ & Phase $2 / 3$ & Inovio Pharmaceuticals & $\begin{array}{l}\text { Center for Pharmaceutical } \\
\text { Research, Kansas City. Mo., } \\
\text { University of Pennsylvania, } \\
\text { Philadelphia }\end{array}$ \\
\hline
\end{tabular}


International Journal of Health Sciences and Pharmacy

(IJHSP), ISSN: 2581-6411, Vol. 5, No. 1, March 2021.

\begin{tabular}{|c|c|c|c|c|}
\hline 17 & $\begin{array}{l}\text { JNJ- } \\
78436735 \\
\text { Viral vector }\end{array}$ & Phase 3 & Johnson \& Johnson & Johnson \& Johnson \\
\hline 18 & $\begin{array}{l}\text { NVX- } \\
\text { CoV2373 } \\
\text { Nanoparticle }\end{array}$ & Phase 3 & Novavax & Novavax \\
\hline 19 & $\begin{array}{l}\text { CVnCoV } \\
\text { mRNA based }\end{array}$ & $\begin{array}{l}\text { Phase } \\
2 b / 3\end{array}$ & GSK, CureVac & CureVac \\
\hline 20 & $\begin{array}{l}\text { VIR- } 7831 \\
\text { Plant based } \\
\text { Adjuvant } \\
\text { vaccine }\end{array}$ & Phase $2 / 3$ & GSK, Medicago, Dynavax & Medicago \\
\hline 21 & $\begin{array}{l}\text { UB- } 612 \\
\text { Multitope } \\
\text { peptide }\end{array}$ & Phase $2 / 3$ & Covaxx & United Biomedical Inc. (UBI) \\
\hline 22 & $\begin{array}{l}\text { EuCorVac- } \\
19 \\
\text { Nanoparticle }\end{array}$ & Phase $1 / 2$ & EuBiologics & Eunpyeong St. Mary's Hospital \\
\hline 23 & $\begin{array}{l}\text { IIBR- } 100 \\
\text { Recombinant } \\
\text { vesicular } \\
\text { stomatitis } \\
\text { virus (rVSV) }\end{array}$ & Phase $1 / 2$ & $\begin{array}{lll}\text { Israel } & \text { Institute } & \text { for } \\
\text { Biological Research } & \end{array}$ & $\begin{array}{l}\text { Hadassah Medical Center; Sheba } \\
\text { Medical Center Hospital }\end{array}$ \\
\hline 24 & $\begin{array}{l}\text { Soberana } 1 \\
\text { and } 2 \\
\text { Monovalent/ } \\
\text { Conjugate }\end{array}$ & Phase $1 / 2$ & Finlay Institute of Vaccines & Finlay Institute of Vaccines \\
\hline 25 & $\begin{array}{l}\text { AG0301- } \\
\text { COVID19 } \\
\text { DNA vaccine }\end{array}$ & Phase $1 / 2$ & $\begin{array}{l}\text { Japan Agency for Medical } \\
\text { Research and Development }\end{array}$ & AnGes, Inc. \\
\hline 26 & $\begin{array}{l}\text { AV-COVID- } \\
19 \\
\text { Dendritic cell } \\
\end{array}$ & Phase 2 & Aivita Biomedical, Inc & $\begin{array}{l}\text { Rumah Sakit Umum Pusat, Dr } \\
\text { Kariadi }\end{array}$ \\
\hline 27 & $\begin{array}{l}\text { COVI-VAC } \\
\text { Intrnasal } \\
\text { vaccine }\end{array}$ & Phase 1 & Codagenix & Serum Institute of India \\
\hline 28 & $\begin{array}{l}\text { PTX- } \\
\text { COVID19-B } \\
\text { mRNA based }\end{array}$ & Phase 1 & Canadian government & Providence Therapeutics \\
\hline 29 & $\begin{array}{l}\text { CORVax12 } \\
\text { DNA vaccine } \\
\text { (Plasmid) }\end{array}$ & Phase 1 & $\begin{array}{l}\text { OncoSec, } \\
\text { Cancer Institute }\end{array}$ & $\begin{array}{l}\text { Providence Portland } \\
\text { Center }\end{array}$ \\
\hline 30 & $\begin{array}{l}\text { AdCOVID } \\
\text { Intranasal } \\
\text { vaccine }\end{array}$ & $\begin{array}{l}\text { Pre } \\
\text { clinical }\end{array}$ & Altimmune & $\begin{array}{l}\text { University of Alabama at } \\
\text { Birmingham }\end{array}$ \\
\hline 31 & $\begin{array}{l}\text { HaloVax } \\
\text { Self } \\
\text { assembling } \\
\text { vaccine }\end{array}$ & $\begin{array}{l}\text { Pre } \\
\text { clinical }\end{array}$ & $\begin{array}{l}\text { Voltron Therapeutics, Inc. } \\
\text { Hoth Therapeutics, Inc. }\end{array}$ & $\begin{array}{lll}\text { MGH } & \text { Vaccine } & \text { and } \\
\text { Immunotherapy Center } & \end{array}$ \\
\hline 32 & $\begin{array}{l}\text { SCB-2019 } \\
\text { Protien } \\
\text { subunit } \\
\text { vaccine }\end{array}$ & Phase 1 & $\begin{array}{l}\text { GlaxoSmithKline, Sanofi, } \\
\text { Clover Biopharmaceuticals, } \\
\text { Dynavax and Xiamen } \\
\text { Innovax; CEPI }\end{array}$ & $\begin{array}{lll}\text { Linear } & \text { Clinical } & \text { Research, } \\
\text { Australia } & & \end{array}$ \\
\hline 33 & PittCoVacc & Pre & UPMC/University & University of Pittsburgh \\
\hline
\end{tabular}




\begin{tabular}{|c|c|c|c|c|}
\hline & $\begin{array}{l}\text { Microneedle } \\
\text { delivered } \\
\text { Recombinant } \\
\text { protein } \\
\text { subunit } \\
\end{array}$ & clinical & $\begin{array}{l}\text { Pittsburgh School of } \\
\text { Medicine }\end{array}$ & \\
\hline 34 & $\begin{array}{l}\text { ChAdOx1 } \\
\text { nCoV- } 19 \\
\text { Recombinant } \\
\text { SARS- CoV- } \\
2 \text { Spike (S) } \\
\text { gylycoprotie } \\
\text { n }\end{array}$ & Phase $2 / 3$ & $\begin{array}{l}\text { Covishield }- \text { Serum } \\
\text { Institute of India Pvt. Ltd., } \\
\text { Cyrus Poonawalla Group } \\
\text { COVID-19 vaccine - } \\
\text { Oxford AstraZeneca }\end{array}$ & $\begin{array}{l}\text { Serum Institute of India Private } \\
\text { Limited, } \\
\text { India }\end{array}$ \\
\hline
\end{tabular}

\section{POSSIBLE FUTURE THERAPEUTIC TARGETS :}

\subsection{Mesenchymal stem cell-based immunomodulation}

To counter the threat of survival of life throughout the world, both pharmaceutical and biotechnology companies are investing their resources to investigate therapeutics or to develop vaccine options. Accordingly, to combat SARS-CoV-2 and COVID-19, both doctors and scientists are focussing their investigation and research on cellular treatments. Through many planned clinical studies on cell-based treatments corona patients have been conducted and reports of these investigations are under progress and are in the process of gathering data. It is observed that pulmonary involvement and development of severe acute respiratory distress syndrome (ARDS) have been found as main contributors of mortality and morbidity in SARS-CoV-2 infection. In this connection, mesenchymal stem cells (MSC) have gained clinical interest as a treatment option due to their immunomodulatory and antifibrotic properties. The mechanisms of action of MSC in the treatment for ARDS is hypothesized to be their anti-inflammatory [105], anti-fibrotic [106], and immunomodulatory [107] properties. Thus, while analyzing the preclinical and early clinical data, and taking into account the overall safety of these cellular therapies MSC seems like a promising option in the treatment of COVID-19 [108].

\subsection{SARS-CoV-2 M-pro Inhibitors}

After the successful crystallisation of a potential drug target COVID-19 main protease (Mpro), several molecular docking studies for bioactive compounds available in some medicinal plants are found to be potential COVID-19 Mpro inhibitors. Investigations can be carried out in this regard, and molecule of kaempferol, quercetin, desmethoxycurcumin, apigenin-7-glucoside, luteolin-7-glucoside, naringenin, curcumin, catechin, oleuropein, and epicatechin-gallate appeared to be have the best potential to act as COVID-19 Mpro inhibitors. However, further research has to be carried out to investigate their potential medicinal use and possibility of intaking them as drug to stabilize the COVID-19 patients [109]. Another research carried out by Aliex et al. (2020) implemented an original virtual screening (VS) protocol to reposition the approved drugs in order to predict the inhibition of the main protease (SARS-CoV-2 M-pro) of the virus, there were seven possible predictions using this approach: Carprofen, Celecoxib, Perampanel, Alprazolam, Sarafloxacin, Trovafloxacin and Ethyl biscoumacetate. The selection of Carprofen and Celecoxib was by the COVID Moonshot initiative for in vitro testing, that showed 3.9\% and $11.9 \%$ of M-pro inhibition at 50 micromolar concentrations respectively [110].

\section{LIMITATIONS :}

Out of the many options of experimental treatments studied so far using different drug molecules or patient stabilizing methods, the main drawback of the study is the inability of generalizing results that is due to used small size samples yielding data that are not found to be statistically significant. This leads to making decisions related to patient treatment on trial and error basis using limited available data. Many other studies were conducted in vitro or in non-human living beings and may not be generalized for use in humans. This review which is based on Pharmacotherapeutic Approach did not consider the variations in clinical data related to treating paediatric, pregnant, or older adult patients as these categories are usually excluded from 
every clinical trial.

\section{CONCLUDING REMARKS :}

The COVID-19 pandemic created the greatest global health crisis of this generation and subsequent economic disaster of the world. In order to tackle this global health hazard, potentially, a number of clinical trials were launched at high speed to handle a suitable treatment procedure and/or effective preventing method. During this critical period, many potential therapies for COVID-19 have been started which enhances both the need and capability to produce high-quality evidence even in the middle of a pandemic situation throughout the world. Accordingly, a systematic review on several available drugs repurposing options considered by different investigation agencies and are being considered for investigation by different agencies are discussed based on pharmacotherapeutic analysis method to control the COVID-19 as there is an urgent requirement for a strong drug or combination of drugs to combat the disease. Some information related to the effectiveness of some potential drugs and immune modulator therapies for the treatment of the SARS-CoV-2. The results of many ongoing clinical trials are yet to be published, it is uncertain whether a single or combination of treatments is effective to manage the pandemic COVID-19. Though the results of many independent trials conducted by many agencies may not be available in near future due to various confidential reasons for the public, one must not underestimate the importance of the efforts of their contributions in the overall progress of the knowledge to slow down the transmission of the disease and optimizing the stabilizing measures.

\section{CONFLICT OF INTEREST :}

The authors confirm that this chapter contents have no conflict of interest.

\section{REFERENCES :}

[1] Wang, C., Horby, P. W., Hayden, F. G., \& Gao, G. F. (2020). A novel coronavirus outbreak of global health concern. The lancet, 395(10223), 470-473.

[2] COVID, W. (2020). 19: USA Available at https://covid19. who. int/region/amro/country/us. Accessibility verified June, 4.

[3] Coronavirus Outbreak. Available at: https://www.worldometers.info/coronavirus/. Accessed on 06 Aug. 2020.

[4] Bai, Y., Yao, L., Wei, T., Tian, F., Jin, D. Y., Chen, L., \& Wang, M. (2020). Presumed asymptomatic carrier transmission of COVID-19. Jama, 323(14), 1406-1407.

[5] Kramer, A., Schwebke, I., \& Kampf, G. (2006). How long do nosocomial pathogens persist on inanimate surfaces? A systematic review. BMC infectious diseases, 6(1), 1-8.

[6] Kampf, G., Todt, D., Pfaender, S., \& Steinmann, E. (2020). Persistence of coronaviruses on inanimate surfaces and their inactivation with biocidal agents. Journal of hospital infection, 104(3), 246-251.

[7] Wang, D., Hu, B., Hu, C., Zhu, F., Liu, X., Peng, Z. (2020). Clinical characteristics of 138 hospitalized patients with 2019 novel coronavirus-infected pneumonia in Wuhan, China. Jama, 323(11), 10611069.

[8] Harapan, H., Itoh, N., Yufika, A., Winardi, W., Keam, S., Te, H., .. \& Mudatsir, M. (2020). Coronavirus disease 2019 (COVID-19): A literature review. Journal of infection and public health, 13(5), 667-673.

[9] Li, Q., Guan, X., Wu, P., Wang, X., Zhou, L., Tong, Y., ... \& Feng, Z. (2020). Early transmission dynamics in Wuhan, China, of novel coronavirus-infected pneumonia. New England journal of medicine. 1-9. DOI: 10.1056/NEJMoa2001316.

[10] Chen N, Zhou M, Dong X, Qu J, Gong F, Han Y, Qiu Y, Wang J, Liu Y, Wei Y, Yu T. (2020). Epidemiological and clinical characteristics of 99 cases of 2019 novel coronavirus pneumonia in Wuhan, China: a descriptive study. The Lancet. 15(395), 507-13.

[11] Huang C, Wang Y, Li X, Ren L, Zhao J, Hu Y, Zhang L, Fan G, Xu J, Gu X, Cheng Z. (2020). Clinical features of patients infected with 2019 novel coronavirus in Wuhan, China. The lancet. 15(395), 497506. 
[12] Chen, N., Zhou, M., Dong, X., Qu, J., Gong, F., Han, Y., ... \& Zhang, L. (2020). Epidemiological and clinical characteristics of 99 cases of 2019 novel coronavirus pneumonia in Wuhan, China: a descriptive study. The lancet, 395(10223), 507-513.

[13] Wang, D., Hu, B., Hu, C., Zhu, F., Liu, X., Zhang, J., ... \& Peng, Z. (2020). Clinical characteristics of 138 hospitalized patients with 2019 novel coronavirus-infected pneumonia in Wuhan, China. Jama, 323(11), 1061-1069.

[14] Chen, H., Guo, J., Wang, C., Luo, F., Yu, X., Zhang, W., ... \& Zhang, Y. (2020). Clinical characteristics and intrauterine vertical transmission potential of COVID-19 infection in nine pregnant women: a retrospective review of medical records. The lancet, 395(10226), 809-815.

[15] Chan, J. F. W., Yuan, S., Kok, K. H., To, K. K. W., Chu, H., Yang, J., ... \& Yuen, K. Y. (2020). A familial cluster of pneumonia associated with the 2019 novel coronavirus indicating person-to-person transmission: a study of a family cluster. The lancet, 395(10223), 514-523.

[16] Das, K. M., Lee, E. Y., Jawder, S. E. A., Enani, M. A., Singh, R., Skakni, L., ... \& Larsson, S. G. (2015). Acute Middle East respiratory syndrome coronavirus: temporal lung changes observed on the chest radiographs of 55 patients. American Journal of Roentgenology, 205(3), W267-S274.

[17] Xie, X., Zhong, Z., Zhao, W., Zheng, C., Wang, F., \& Liu, J. (2020). Chest CT for typical coronavirus disease 2019 (COVID-19) pneumonia: relationship to negative RT-PCR testing. Radiology, 296(2), E41-E45.

[18] Chung M, Bernheim A, Mei X, Zhang N, Huang M, Zeng X, Cui J, Xu W, Yang Y, Fayad ZA, Jacobi A. (2020). CT imaging features of 2019 novel coronavirus (2019-nCoV). Radiology. 295(1), 202-207.

[19] Pan, F., Ye, T., Sun, P., Gui, S., Liang, B., Li, L., ... \& Zheng, C. (2020). Time course of lung changes on chest CT during recovery from 2019 novel coronavirus (COVID-19) pneumonia. Radiology, 295(3), 715-721.

[20] Shi, H., Han, X., Jiang, N., Cao, Y., Alwalid, O., Gu, J., ... \& Zheng, C. (2020). Radiological findings from 81 patients with COVID-19 pneumonia in Wuhan, China: a descriptive study. The Lancet infectious diseases, 20(4), 425-434.

[21] Xu, X., Yu, C., Qu, J., Zhang, L., Jiang, S., Huang, D., ... \& Liu, J. (2020). Imaging and clinical features of patients with 2019 novel coronavirus SARS-CoV-2. European journal of nuclear medicine and molecular imaging, 47(5), 1275-1280.

[22] Wang, Y., Kang, H., Liu, X., \& Tong, Z. (2020). Combination of RT-qPCR testing and clinical features for diagnosis of COVID-19 facilitates management of SARS-CoV-2 outbreak. Journal of medical virology, 92(6), 538-539.

[23] Habibzadeh, P., \& Stoneman, E. K. (2020). The novel coronavirus: a bird's eye view. The international journal of occupational and environmental medicine, 11(2), 65-71.

[24] Cascella, M., Rajnik, M., Cuomo, A., Dulebohn, S. C., \& Di Napoli, R. (2020). Features, evaluation and treatment coronavirus (COVID-19). Statpearls [internet].

[25] Wu, C. N., Xia, L. Z., Li, K. H., Ma, W. H., Yu, D. N., Qu, B., ... \& Cao, Y. (2020). High-flow nasaloxygenation-assisted fibreoptic tracheal intubation in critically ill patients with COVID-19 pneumonia: a prospective randomised controlled trial. British journal of anaesthesia, 125(1), e166-e168.

[26] Holshue, M. L., DeBolt, C., Lindquist, S., Lofy, K. H., Wiesman, J., Bruce, H., ... \& Pillai, S. K. (2020). First case of 2019 novel coronavirus in the United States. New England Journal of Medicine, 382(1), 929-936.

[27] Xia, S., Liu, M., Wang, C., Xu, W., Lan, Q., Feng, S., ... \& Lu, L. (2020). Inhibition of SARS-CoV-2 (previously 2019-nCoV) infection by a highly potent pan-coronavirus fusion inhibitor targeting its spike protein that harbors a high capacity to mediate membrane fusion. Cell research, 30(4), 343-355.

[28] CDC. Coronavirus disease 2019 (COVID-19). Centers for Disease Control and Prevention (2020). Available from: https://www.cdc.gov/coronavirus/2019-ncov/hcp/therapeutic-options.html 
[29] Adaptive COVID-19 Treatment Trial - Full Text View - ClinicalTrials.gov. Available from: https://clinicaltrials.gov/ct2/show/NCT04280705

[30] Wang, M., Cao, R., Zhang, L., Yang, X., Liu, J., Xu, M., ... \& Xiao, G. (2020). Remdesivir and chloroquine effectively inhibit the recently emerged novel coronavirus (2019-nCoV) in vitro. Cell research, 30(3), 269-271.

[31] NIH Clinical Trials. Efficacy and safety of hydroxyChloroquine for treatment of pneumonia caused by 2019-nCoV (HC-nCoV) (2020). https://clinicaltrials.gov/ct2/show/NCT04261517

[32] Gao, J., Tian, Z., \& Yang, X. (2020). Breakthrough: Chloroquine phosphate has shown apparent efficacy in treatment of COVID-19 associated pneumonia in clinical studies. Bioscience trends, P1P2.

[33] Boriskin, Y. S., Leneva, I. A., Pecheur, E. I., \& Polyak, S. J. (2008). Arbidol: a broad-spectrum antiviral compound that blocks viral fusion. Current medicinal chemistry, 15(10), 997-1005.

[34] Khamitov, R. A., SIa, L., Shchukina, V. N., Borisevich, S. V., Maksimov, V. A., \& Shuster, A. M. (2008). Antiviral activity of arbidol and its derivatives against the pathogen of severe acute respiratory syndrome in the cell cultures. Voprosy virusologii, 53(4), 9-13.

[35] Lu, H. (2020). Drug treatment options for the 2019-new coronavirus (2019-nCoV). Bioscience trends, 14(1), 69-71.

[36] Chinese Clinical Trial Registry. A randomized controlled trial for the efficacy and safety of Baloxavir Marboxil, Favipiravir tablets in novel coronavirus pneumonia (COVID-19) patients who are still positive on virus detection under the current antiviral therapy (2020). http://www.chictr.org.cn/showprojen.aspx ?proj=49013

[37] Ford, N., Vitoria, M., Rangaraj, A., Norris, S. L., Calmy, A., \& Doherty, M. (2020). Systematic review of the efficacy and safety of antiretroviral drugs against SARS, MERS or COVID-19: initial assessment. Journal of the International AIDS Society, 23(4), e25489.

[38] Gautret, P., Lagier, J. C., Parola, P., Meddeb, L., Mailhe, M., Doudier, B., ... \& Raoult, D. (2020). Hydroxychloroquine and azithromycin as a treatment of COVID-19: results of an open-label nonrandomized clinical trial. International journal of antimicrobial agents, 56(1), 105949.

[39] Gibson, P. G., Yang, I. A., Upham, J. W., Reynolds, P. N., Hodge, S., James, A. L., ... \& Simpson, J. L. (2017). Effect of azithromycin on asthma exacerbations and quality of life in adults with persistent uncontrolled asthma (AMAZES): a randomised, double-blind, placebo-controlled trial. The Lancet, 390(10095), 659-668.

[40] Damle, B., Vourvahis, M., Wang, E., Leaney, J., \& Corrigan, B. (2020). Clinical pharmacology perspectives on the antiviral activity of azithromycin and use in COVID-19. Clinical Pharmacology \& Therapeutics, 108(2), 201-211.

[41] Halley, B. A., Nessel, R. J., \& Lu, A. Y. H. (1989). Environmental aspects of ivermectin usage in livestock: general considerations. In Ivermectin and abamectin (pp. 162-172). Springer, New York, NY.

[42] Chaccour, C., Hammann, F., Ramón-García, S., \& Rabinovich, N. R. (2020). Ivermectin and COVID19: keeping rigor in times of urgency. The American journal of tropical medicine and hygiene, 102(6), 1156.

[43] Khatri, M., \& Mago, P. (2020). Nitazoxanide/Camostat combination for COVID-19: An unexplored potential therapy. Chemical Biology Letters, 7(3), 192-196.

[44] Mahmoud, D. B., Shitu, Z., \& Mostafa, A. (2020). Drug repurposing of nitazoxanide: can it be an effective therapy for COVID-19?. Journal of Genetic Engineering and Biotechnology, 18(1), 1-10.

[45] Rizk, J. G., Kalantar-Zadeh, K., Mehra, M. R., Lavie, C. J., Rizk, Y., \& Forthal, D. N. (2020). Pharmaco-immunomodulatory therapy in COVID-19. Drugs, 1-26. 
[46] Seif, F., Khoshmirsafa, M., Aazami, H., Mohsenzadegan, M., Sedighi, G., \& Bahar, M. (2017). The role of JAK-STAT signaling pathway and its regulators in the fate of $\mathrm{T}$ helper cells. Cell communication and signaling, 15(1), 1-13.

[47] Elli, E. M., Baratè, C., Mendicino, F., Palandri, F., \& Palumbo, G. A. (2019). Mechanisms underlying the anti-inflammatory and immunosuppressive activity of ruxolitinib. Frontiers in oncology, 9(1186), $1-10$.

[48] Gaspari, V., Zengarini, C., Greco, S., Vangeli, V., \& Mastroianni, A. (2020). Side effects of ruxolitinib in patients with SARS-CoV-2 infection: two case reports. International journal of antimicrobial agents, 56(2), 1-2.

[49] Richardson, P., Griffin, I., Tucker, C., Smith, D., Oechsle, O., Phelan, A., \& Stebbing, J. (2020). Baricitinib as potential treatment for 2019-nCoV acute respiratory disease. Lancet (London, England), 395(10223), e30.

[50] Stebbing, J., Phelan, A., Griffin, I., Tucker, C., Oechsle, O., Smith, D., \& Richardson, P. (2020). COVID-19: combining antiviral and anti-inflammatory treatments. The Lancet Infectious Diseases, 20(4), 400-402.

[51] Lilly Begins Clinical Testing of Therapies for COVID-19. Press release. Lilly. https://investor.lilly.com/news-releases/news-release-details/lilly-begins-clinicaltesting-therapiescovid-19.

[52] National Institutes of Health. Coronavirus disease 2019 (COVID-19) treatment guidelines. https://www.covid19treatmentguidelines.nih.gov/). Accessed 11 May 2020.

[53] Lefebvre, A. L., \& McAuliffe, L. (2016). Targeted Immunomodulatory Therapy: An Overview. Rhode Island Medical Journal, 99(12), 19-22.

[54] Wang, L., He, W., Yu, X., Hu, D., Bao, M., Liu, H., ... \& Jiang, H. (2020). Coronavirus disease 2019 in elderly patients: characteristics and prognostic factors based on 4-week follow-up. Journal of Infection, 80(6), 639-645.

[55] Hussell, T., Pennycook, A., \& Openshaw, P. J. (2001). Inhibition of tumor necrosis factor reduces the severity of virus-specific lung immunopathology. European journal of immunology, 31(9), 2566-2573.

[56] Haga, S., Yamamoto, N., Nakai-Murakami, C., Osawa, Y., Tokunaga, K., Sata, T., ... \& Ishizaka, Y. (2008). Modulation of TNF- $\alpha$-converting enzyme by the spike protein of SARS-CoV and ACE2 induces TNF- $\alpha$ production and facilitates viral entry. Proceedings of the National Academy of Sciences, 105(22), 7809-7814.

[57] Feldmann, M., Maini, R. N., Woody, J. N., Holgate, S. T., Winter, G., Rowland, M., ... \& Hussell, T. (2020). Trials of anti-tumour necrosis factor therapy for COVID-19 are urgently needed. The Lancet, 395(10234), 1407-1409.

[58] Mahase, E. (2020). Covid-19: what treatments are being investigated?.

[59] Vandewalle, J., Luypaert, A., De Bosscher, K., \& Libert, C. (2018). Therapeutic mechanisms of glucocorticoids. Trends in Endocrinology \& Metabolism, 29(1), $42-54$.

[60] Rhen, T., \& Cidlowski, J. A. (2005). Antiinflammatory action of glucocorticoids-new mechanisms for old drugs. New England Journal of Medicine, 353(16), 1711-1723.

[61] Matthay, M. A., Zemans, R. L., Zimmerman, G. A., Arabi, Y. M., Beitler, J. R., Mercat, A., ... \& Calfee, C. S. (2019). Acute respiratory distress syndrome. Nature reviews Disease primers, 5(1), 1-22.

[62] Lamontagne, F., Rochwerg, B., Lytvyn, L., Guyatt, G. H., Møller, M. H., Annane, D., ... \& Siemieniuk, R. A. (2018). Corticosteroid therapy for sepsis: a clinical practice guideline. $b m j, 362(1), 1-8$.

[63] Nicastri, E., Petrosillo, N., Ascoli Bartoli, T., Lepore, L., Mondi, A., Palmieri, F., ... \& Ippolito, G. (2020). National institute for the infectious diseases "L. Spallanzani" IRCCS. Recommendations for COVID-19 clinical management. Infectious disease reports, 12(1), 3-9. 
[64] Russell, D., J.E. Millar, J.K. Baillie. (2020). Clinical evidence does not support corticosteroid treatment for 2019-CoV lung injury. Lancet, 395(2020), 473-475.

[65] Cochrane Database Syst Rev. (2019). Pharmacological agents for adults with acute respiratory distress syndrome. 10.1002/14651858.CD004477.pub3PMID: 31334568.

[66] B. Brody, Prednisone and coronavirus: Do corticosteroids Make You immunosuppressed and Higher Risk for COVID-19? Available at creacyjoints.org (2020). Accessed on March 30, 2020.

[67] National Health Commission \& State Administration of traditional Chinese medicine. Diagnosis and treatment protocol for novel coronavirus pneumonia. From China consulate website. Accessed 2020 Mar 20. http://busan.china consulate.org/chn/zt/4/P020200310548447287942.pdf (2020).

[68] Centers for Disease Control and Prevention. Interim Clinical Guidance for Management of Patients with Confirmed 2019 Novel Coronavirus (2019-nCoV, https://www.cdc.gov/vaccines/covid-19/infoby-product/clinical-considerations.html. Accessed on March 30, 2020.

[69] Shen, L., Mo, H., Cai, L., Kong, T., Zheng, W., Ye, J., ... \& Xiao, Z. (2009). Losartan prevents sepsisinduced acute lung injury and decreases activation of nuclear factor $\mathrm{\kappa B}$ and mitogen-activated protein kinases. Shock, 31(5), 500-506.

[70] Wang, L., Shi, Y., Xiao, T., Fu, J., Feng, X., Mu, D., ... \& Zhou, W. (2020). Chinese expert consensus on the perinatal and neonatal management for the prevention and control of the 2019 novel coronavirus infection. Annals of translational medicine, 8(3), 47, 1-8.

[71] McGonagle, D., O'Donnell, J. S., Sharif, K., Emery, P., \& Bridgewood, C. (2020). Immune mechanisms of pulmonary intravascular coagulopathy in COVID-19 pneumonia. The Lancet Rheumatology, 2(7), 1-9.

[72] Satoh, M., Takahashi, Y., Tabuchi, T., Minami, Y., Tamada, M., Takahashi, K., ... \& Nakamura, M. (2015). Cellular and molecular mechanisms of statins: an update on pleiotropic effects. Clinical Science, 129(2), 93-105.

[73] Esteve-Valverde, E., Ferrer-Oliveras, R., Gil-Aliberas, N., Baraldès-Farré, A., Llurba, E., \& AlijotasReig, J. (2018). Pravastatin for preventing and treating preeclampsia: a systematic review. Obstetrical \& gynecological survey, 73(1), 40-55.

[74] Fedson, D. S. (2015). A practical treatment for patients with Ebola virus disease. The Journal of infectious diseases, 211(4), 661-662.

[75] Fedson, D. S., Opal, S. M., \& Rordam, O. M. (2020). Hiding in plain sight: an approach to treating patients with severe COVID-19 infection. MBio, 11(2), 1-3.

[76] Shyamsundar, M., McKeown, S. T., O'Kane, C. M., Craig, T. R., Brown, V., Thickett, D. R., ... \& McAuley, D. F. (2009). Simvastatin decreases lipopolysaccharide-induced pulmonary inflammation in healthy volunteers. American journal of respiratory and critical care medicine, 179(12), 1107-1114.

[77] M. Heng, H. Yu. Characteristics, causes, diagnosis and treatment of coagulation dysfunction in patients with COVID-19. Chin J Hematol, 41(2020), 10.3760/cma.j.issn.0253-2727.2020.0002

[78] Zhou, F., Yu, T., Du, R., Fan, G., Liu, Y., Liu, Z., ... \& Cao, B. (2020). Clinical course and risk factors for mortality of adult inpatients with COVID-19 in Wuhan, China: a retrospective cohort study. The lancet, 395(10229), 1054-1062.

[79] Stockman, L. J., Bellamy, R., \& Garner, P. (2006). SARS: systematic review of treatment effects. PLoS med, 3(9), e343.

[80] Ng, K. H. L., Wu, A. K. L., Cheng, V. C. C., Tang, B. S. F., Chan, C. Y., Yung, C. Y., ... \& Yuen, K. Y. (2005). Pulmonary artery thrombosis in a patient with severe acute respiratory syndrome. Postgraduate medical journal, 81(956), e3-e3.

[81] Danzi, G. B., Loffi, M., Galeazzi, G., \& Gherbesi, E. (2020). Acute pulmonary embolism and COVID19 pneumonia: a random association?. European heart journal, 41(19), 1858-1858. 
[82] Zuckier, L. S., Moadel, R. M., Haramati, L. B., \& Freeman, L. M. (2020). Diagnostic evaluation of pulmonary embolism during the COVID-19 pandemic. Journal of Nuclear Medicine, 61(5), 630-631.

[83] Shoenfeld, Y. (2020). Corona (COVID-19) time musings: our involvement in COVID-19 pathogenesis, diagnosis, treatment and vaccine planning. Autoimmunity reviews.

[84] Chang, Y., \& Wei, W. (2015). Angiotensin II in inflammation, immunity and rheumatoid arthritis. Clinical \& Experimental Immunology, 179(2), 137-145.

[85] Lu, R., Zhao, X., Li, J., Niu, P., Yang, B., Wu, H., ... \& Tan, W. (2020). Genomic characterisation and epidemiology of 2019 novel coronavirus: implications for virus origins and receptor binding. The lancet, 395(10224), 565-574.

[86] Kuba, K., Imai, Y., Rao, S., Gao, H., Guo, F., Guan, B., ... \& Penninger, J. M. (2005). A crucial role of angiotensin converting enzyme 2 (ACE2) in SARS coronavirus-induced lung injury. Nature medicine, 11(8), 875-879.

[87] Imai, Y. Kuba K, Rao S, Huan Y, Guo F, Guan B, Yang P, Sarao R, Wada T, Leong-Poi H, Crackower MA, Fukamizu A, Hui CC, Hein L, Uhlig S, Slutsky AS, Jiang C, Penninger JM. Angiotensinconverting enzyme, 2(1), 112-116.

[88] Tikellis, C., Bernardi, S., \& Burns, W. C. (2011). Angiotensin-converting enzyme 2 is a key modulator of the renin-angiotensin system in cardiovascular and renal disease. Current opinion in nephrology and hypertension, 20(1), 62-68.

[89] Reynolds, H. R., Adhikari, S., Pulgarin, C., Troxel, A. B., Iturrate, E., Johnson, S. B., ... \& Hochman, J. S. (2020). Renin-angiotensin-aldosterone system inhibitors and risk of Covid-19. New England Journal of Medicine, 382(25), 2441-2448.

[90] Mancia, G., Rea, F., Ludergnani, M., Apolone, G., \& Corrao, G. (2020). Renin-angiotensinaldosterone system blockers and the risk of Covid-19. New England Journal of Medicine, 382(25), 2431-2440.

[91] Curfman, G. (2020). Renin-angiotensin-aldosterone inhibitors and susceptibility to and severity of COVID-19. Jama, 324(2), 177-178.

[92] Bloch, E. M., Shoham, S., Casadevall, A., Sachais, B. S., Shaz, B., Winters, J. L., ... \& Tobian, A. A. (2020). Deployment of convalescent plasma for the prevention and treatment of COVID-19. The Journal of clinical investigation, 130(6), 2757-2765.

[93] Tiberghien, P., de Lamballerie, X., Morel, P., Gallian, P., Lacombe, K., \& Yazdanpanah, Y. (2020). Collecting and evaluating convalescent plasma for COVID-19 treatment: why and how? Vox sanguinis, 115(6), 488-494.

[94] Roback, J. D., \& Guarner, J. (2020). Convalescent plasma to treat COVID-19: possibilities and challenges. Jama, 323(16), 1561-1562.

[95] Casadevall, A., \& Pirofski, L. (13). March 2020, posting date. The convalescent sera option for containing COVID-19. J Clin Invest. https://doi. org/10.1172/JCI138003.

[96] Cunningham, A. C., Goh, H. P., \& Koh, D. (2020). Treatment of COVID-19: old tricks for new challenges. Critical Care, 24(91), 1-2.

[97] Rojas, M., Rodríguez, Y., Monsalve, D. M., Acosta-Ampudia, Y., Camacho, B., Gallo, J. E., ... \& Anaya, J. M. (2020). Convalescent plasma in Covid-19: Possible mechanisms of action. Autoimmunity reviews, 19(7), 1-9.

[98] Soo, Y. O. Y., Cheng, Y., Wong, R., Hui, D. S., Lee, C. K., Tsang, K. K. S., ... \& Sung, J. J. Y. (2004). Retrospective comparison of convalescent plasma with continuing high-dose methylprednisolone treatment in SARS patients. Clinical microbiology and infection, 10(7), 676-678.

[99] Arabi, Y., Balkhy, H., Hajeer, A. H., Bouchama, A., Hayden, F. G., Al-Omari, A., ... \& Fowler, R. (2015). Feasibility, safety, clinical, and laboratory effects of convalescent plasma therapy for patients 
with Middle East respiratory syndrome coronavirus infection: a study protocol. Springerplus, 4(1), 18.

[100] Hung, I. F., To, K. K., Lee, C. K., Lee, K. L., Chan, K., Yan, W. W., ... \& Yuen, K. Y. (2011). Convalescent plasma treatment reduced mortality in patients with severe pandemic influenza A (H1N1) 2009 virus infection. Clinical Infectious Diseases, 52(4), 447-456.

[101] Mair-Jenkins, J., Saavedra-Campos, M., Baillie, J. K., Cleary, P., Khaw, F. M., Lim, W. S., ... \& Beck, C. R. (2015). Convalescent Plasma Study Group The effectiveness of convalescent plasma and hyperimmune immunoglobulin for the treatment of severe acute respiratory infections of viral etiology: a systematic review and exploratory meta-analysis. J Infect Dis, 211(1), 80-90.

[102] Shen, C., Wang, Z., Zhao, F., Yang, Y., Li, J., Yuan, J., ... \& Liu, L. (2020). Treatment of 5 critically ill patients with COVID-19 with convalescent plasma. Jama, 323(16), 1582-1589.

[103] https://www.sciencemag.org/news/2020/08/russia-s-approval-covid-19-vaccine-less-meets-press$\underline{\text { release }}$

[104] https://www.raps.org/news-and-articles/news-articles/2020/3/covid-19-vaccine-tracker Referred on 20/08/2020.

[105] Prockop, D. J., \& Oh, J. Y. (2012). Mesenchymal stem/stromal cells (MSCs): role as guardians of inflammation. Molecular therapy, 20(1), 14-20.

[106] Bernardo, M. E., \& Fibbe, W. E. (2013). Mesenchymal stromal cells: sensors and switchers of inflammation. Cell stem cell, 13(4), 392-402.

[107] Wang, M., Yuan, Q., \& Xie, L. (2018). Mesenchymal stem cell-based immunomodulation: properties and clinical application. Stem Cells International, 2018(1),1-12.

[108] Gonzalez, J. A., Gonzalez, R. R., \& Ayala, L. E. (2020). Mesenchymal Stem Cells Therapy for Coronavirus COVID-19 Induced ARDS: A Promising Concept. Global Journal of Medical, Pharmaceutical, and Biomedical Update, 15(1), 1-5.

[109] Khaerunnisa, S., Kurniawan, H., Awaluddin, R., Suhartati, S., \& Soetjipto, S. (2020). Potential inhibitor of COVID-19 main protease (Mpro) from several medicinal plant compounds by molecular docking study, 1-14. https://www.mastcellmaster.com/PDF/16/Hyperlink-to-Ref-21.pdf

[110] Gimeno, A., Mestres-Truyol, J., Ojeda-Montes, M. J., Macip, G., Saldivar-Espinoza, B., CeretoMassagué, A., ... \& Garcia-Vallvé, S. (2020). Prediction of novel inhibitors of the main protease (Mpro) of SARS-CoV-2 through consensus docking and drug reposition. International journal of molecular sciences, 21(11), 3793. 